\title{
The Potential of Local Culture in English Language Teaching (ELT): A Response Paper to Domination of English Material in ELT
}

\author{
Ni Luh Putu Indah Yusniawati* \\ Postgraduate English Departement \\ University of Mataram \\ Mataram, Indonesia \\ putuindah12@gmail.com
}

\author{
Yuni Budi Lestari \\ Postgraduate English Departement \\ University of Mataram \\ Mataram, Indonesia \\ lestariyuni2006@gmail.com
}

\begin{abstract}
Language and culture have been widely assumed to be inseparable. Under this assumption learning language requires learning the culture of the target language. In ELT context, this suggests the ELT practices that use learning materials, activities and teaching approaches related to English culture. While these practices have been widely believed to be very useful for successful English learning, they have been greatly questioned as they might not be suitable with students' own or local contexts or culture. This paper presents a result of a theoretical review-based study on the potential of using local cultural materials under the domination of Western cultural materials in EFL context. The data in the study include selected books, review articles and empirical research articles. PQRS (Preview, Question, Read, Summarize) was used as the method of data analysis. From the study, it was found that Vigotsky's social development theory, schemata theory and the phenomenon of World Englishes strongly support the use of local cultural in ELT. The theories suggest that using local culture-related materials in EFL classrooms, teachers would potentially facilitate students to achieve English competencies while resisting the domination of English material in English language teaching.
\end{abstract}

Keywords - local culture, learning material, World Englishes.

\section{INTRODUCTION}

Language and culture have been widely believed to be inseparable. This is because, as stated [1]-[2], language is a means of representing culture. This belief has led to the dominant use of English material in ELT and has only given little attention to the use of local culture-related material. Indeed, the idea of using local culture in English as a Foreign Language (EFL) classrooms has long been frown at particularly at the advent of communicative and competency-based language teaching [3]. To Richards and Farrel [3], learning a target language is also learning the culture of the target language. This idea is dangerous to societies which view English-speaking cultures as inappropriate [23]. To them, English is essential for better jobs and better life but culture and religious tradition are also important for happier, more enjoyable, and more sociallyacceptable way of life. Thus, enforcing the language and the local cultural learning has imposed an unsolved dilemma to the students and the parents who expect their children to maintain their own culture. Lestari [4] and Yusra [5] have described this dilemma to a certain extent: on the one hand, teachers have to teach English language and culture, but, on the other, they have to integrate Indonesian cultures as expected in the character-based Indonesian Curriculum 2013. This localized curriculum receives some strong theoretical support as explained in the following session.

The rural students, however, do not come to English classes empty-handed. They bring with them, following Bourdieu [6], some essentially useful assets. They have motivation and propensity to learn English due to locally available promising jobs in tourism and mining industries. They also bring with them with the knowledge of how things work in their culture and that in the world. They bring with them their native languages in which stories are told, people and things are described, food and other cultural products are made, arguments are expressed, and other cultural practices are laid out. Thus, as Goffman [7] would suggest, they bring with them textual and procedural knowledge. If this knowledge is brought to EFL classes, the students, at least, do not have to learn from scratch, i.e. learning the language and learning the contents at the same time. If local knowledge is used, the students have acquired at least the meanings (i.e. the content and the procedure) and they only need to learn the language in which the content and the procedure are expressed. Indeed, this will make life easier for the students as they can guess the meaning of words or sentences based on the cultural and procedural schemata that they have developed in the native languages.

\section{METHODS}

This study is literature reviewed based. A systematic review of literature was used in this study. A systematic review is most likely helpful to generate more comprehensive review [8]. This study involves several procedures. The first procedure is searching and selecting appropriate and related sources. The selected and collected sources were then analysed to identify important information in it. The last step is drawing a conclusion from the selected sources as a group.

The data used in the study comprises selected books, review articles and empirical research articles appropriate and related to the topic on the use of local culture in English language teaching. The data were analysed using Preview, Question, Read, Summarize (PQRS). This method of data analysis, as Cronin, et al [8] suggest, helps with a more focused and easy identification of material under investigation. 


\section{RESULT AND DISCUSSION}

This section presents and discusses the findings from the literature. From the data it was found strong theoretical support for the potential use of local culture in ELT. The theories include Vigotsky's social development theory, schemata theory and the phenomenon of World Englishes. This is discussed in the following the following sub section.

\section{Theoretical Support for the Potential use of local Culture in ELT}

Learning culture has been seen critical to language learning development. Hymes [9], with his Communicative Competence claims that to communicate effectively in a target language, language learners or speakers need more than grammatical competence, which is sociocultural competence. This is confirmed by Schuman [10] with his acculturation theory model suggesting that greater success on language acquisition is gained through being immersed into the target society or culture. The advent of communicative and competency-based language teaching further emphasizes the incorporation of culture into language learning (Brown, 2001) [11]. To them, learning a target language is also learning the culture of the target language. While, none of those theorists discuss the role of local culture in target language learning, some other theorists suggest the positive contribution of local culture in target language learning.

Lev Vigotsky's Social development theory has actually implied the contribution of local culture in target language learning. The theory argues that humans use tools from their culture to communicate their needs [12]. Vigostky further believed that the internalization of these cultural tools led to higher level of cognitive skills [12]. Support for local culture integration into target language learning has also come from Schemata theory arguing that to understand a text, one is required to make connections between what is said or written and his schema or mind [13]. One of the schemas occupying one's mind is culture-specific content schema [14] which has been proved to greatly influence reading comprehension process [15]-[16]. This means that if this cultural knowledge, as Goffman [7] would refer to textual and procedural knowledge, is brought to EFL classes, the students have acquired at least the meanings (i.e., the content and the procedure) and they only need to learn the language in which the content and the procedure are expressed. This will make life easier for the students as they can guess the meaning of words or sentences based on the cultural and procedural schemata that they have developed in the native languages.

Indeed, the students do not come to English classes empty-handed. They bring with them, following Bourdieu [6], some essentially useful assets. They have motivation and propensity to learn English due to locally available promising jobs in tourism and mining industries. They also bring with them with the knowledge of how things work in their culture and that in the world. They bring with them their native languages in which stories are told, people and things are described, food and other cultural products are made, arguments are expressed, and other cultural practices are laid out.
With the phenomenon of World Englishes [17], however, it seems no longer relevant to refer target culture to the one belonging to people from Inner circle countries including the United Kingdom, the United States, Canada, Australia and New Zealand. This is because English is used more by people from Outer-Circle and Expanding-Circler than by those from Inner-circle. Kirkpatrick [21] has also argued that when English appears to have been accepted as a Lingua Franca, non-native speaker of English learns English in order to be able to communicate with their fellow nonnative speakers at regional contexts. He further suggests that there should be a shift in English curriculum from focusing on an understanding of 'Anglo' cultures to regional cultures (p.214). Pragmatic and cultural norms and values of the learners, therefore, should be reflected in the curriculum of a new variety of English [20], giving a place to preserve the students' identity [21]. In this way, local culture is given prominence in English language learning.

The demand of "intercultural speaker" on a language learner in the context of English as an International language [22] might have challenged the solely use of local culture in English language teaching. Several studies focusing on the implementation of communicative language teaching in Asian countrs, however, have shown that despite desire to acquire international variety of English, students favour more local cultural norms and values [23]. In fact, integration of local culture in teaching English has been proven to be effective in increasing students' engagement cognitively and affectively [24]. Other studies have also shown that the use of local cultural material is effective to be used in improving students' English language skills, not only in reading but also in writing, listening, and speaking [25][26]. Moreover, Nambiar [26] reported that the students' confidence in learning English also increased when local cultural related material was used in EFL classrooms.

The fact that English has been going through the process of "nativization" in Outer and Expanding circles [18] which makes it an international language implies the conformity of using local cultural resources in language learning. Ramly, Othman \& Mclellan [27] have clearly described how nativized English in Malaysia is used in both formal and informal contexts and functions to show local cultural identity. "Nativization" process of English can also be clearly seen in Pakistan. [28] analysing ELT textbooks in Pakistani secondary schools, has shown discursively how a variety of Pakistani English has been used to represent Islamic experiences, culture and ideologies. Such Islamic representation would be favourable by parents in other Muslim societies such as Saudi Arabia and Iran which view that 'Western cultures' contain inappropriate cultural practices from their children [30]. While he argues that the new varieties of English reflect resistance to colonial discourse, in another similar research he reveals that English language is appropriated by textbook writers to promote particular belief and carry out identity management which limit students' access to semiotic resources creating students' restricted understanding of worldview [28]. In other words, the teaching of culture is always an integral part of curriculum. It is, therefore, important to work under the framework of critical pedagogy requiring teaching to use local culture in effective way. Indeed, as students are familar with their own culture, it is potential for them to think 
ciritically since they better understand problems in their local contexts and solve them [29].

\section{CONCLUSION}

The widely agreed assumption on the inseparability of language and culture has resulted in the dominant use of ELT material containing culture related to inner circle countries such as the USA, Canada, the UK, Australia and New Zealand. Some strong theoretical rationales, however, have suggested the local culture could be potentially used in EFL classrooms. Vigotsky's social development theory, schemata theory, and the phenomenon of World Englishes are among the theories strongly supporting the integration of local culture into English language teaching. Theories have been scientifically verified by a number of emprical studies conducted in different EFL contexts. The empirical studies have also found that the use of local culture could improve the students' reading, writing, speaking and listening competencies. Accordingly, using local culture-related materials in EFL classrooms, teachers would potentially facilitate students to achieve English competencies while resisting the domination of English material in English language teaching. Indonesian national curriculum's recommendation on the integration of students' local culture into English language material should then be accomodated by English teachers, policy agents and stake holders at local contexts.

\section{REFERENCES}

[1] Fishman Joshua. "The Truth about Language and Culture (and a Note about its Relevance to the Jewish Case)". The International Journal of the Sociology of Language, (1994). 109: 83-96.

[2] Brown, H. Douglas. Principles of language learning and teaching. Vol. 4. New York: Longman, 2000

[3] Richards, Jack C., and Thomas Sylvester Charles Farrell. Professional development for language teachers: Strategies for teacher learning. Ernst Klett Sprachen, 2005.

[4] Lestari, Yuni Budi. "Local Cultural Practices in Teacher Agentic Responses to English as a Foreign Language (EFL) Curriculum: A Lesson Learned from Indonesia." UNNES International Conference on English Language Teaching, Literature, and Translation (ELTLT 2018). Atlantis Press, 2019.

[5] Yusra, Kamaludin, and Yuni Budi Lestari. "Integrating Attitude, Knowledge and Skills in K-13 English Lesson Plans: Explorations into Teachers' Agentic Roles in Materials Development." The Asian EFL Journal Quarterly March 2018 Volume 20, Issue 3 (2018): 176.

[6] Bourdieu, Pierre. Language and symbolic power. Harvard University Press, 1991.

[7] Face-Work, On. "In Interaction Ritual: Essays on Face-to-Face Behavior.". 1967: 5-45.

[8] Cronin, Patricia, Frances Ryan, and Michael Coughlan. "Undertaking a literature review: a step-by-step approach." British journal of nursing 17.1 . 2008: 38-43

[9] Hymes, Dell. "Toward ethnographies of communication: The analysis of communicative events." Language and social context. 1972: 21-44
[10] Schumann, John H. "Research on the acculturation model for second language acquisition." Journal of multilingual \& multicultural development 7.5. 1986: 379-392.

[11] Douglas, D. A. N., and Stefan Frazier. "Teaching by Principles: An Interactive Approach to Language Pedagogy .: H. Douglas Brown." 2001: 341-342.

[12] Driscoll, Marcy Perkins, and Kerry Jean Burner. "Psychology of learning for instruction.". 2005.

[13] Young, J., J. Klosko, and M. Weishaar. "Schema Therapy: A Practitioner's Guide. New York.". 2003.

[14] Carrell, Patricia L., and Joan C. Eisterhold. "Schema theory and ESL reading pedagogy." TESOL quarterly 17.4. 1983: 553-573.

[15] Johnson, Patricia. "Effects on ReadinComprehension of building background knowledge." TESOL quarterly 16.4. 1982: 503-516.

[16] Steffensen, M. S. "Joag-Dev. C.(1984). Cultural knowledge and reading." Reading in a foreign language (85): 48-62.

[17] Kachru, Braj B. "World Englishes: Approaches, issues and resources." Language teaching 25.1. 1992: 1-14.

[18] Kachru, Braj B. "World Englishes 2000: Resources for research and teaching." Literary Studies 14. 1997: 209-251.

[19] Celce-Murcia, Marianne. "Grammar pedagogy in second and foreign language teaching." TESOL quarterly 25.3. 1991: 459-480.

[20] Datesman, Maryanne Kearny, Jo Ann Crandall, and Edward N. Kearny. American ways: An introduction to American culture. Longman, 2005

[21] Kirkpatrick, Andy. "ASEAN and Asian cultures and models: Implications for the ELT curriculum and for teacher selection." Englishes in Asia: Communication, identity, power and education. 2002: 213-224

[22] Kramsch, Claire. "Culture in foreign language teaching." Iranian Journal of Language Teaching Research 1.1. 2013: 57-78.

[23] Kumaravadivelu, Bala. "Dangerous liaison: Globalization, empire and TESOL." (Re-) locating TESOL in an age of empire. Palgrave Macmillan, London, 2006. 1-26.

[24] Lestari, Yuni Budi. "Integration of local texts and cultural practices in localised EFL classrooms: An ethnographic study of a rural Indonesian school.". 2020

[25] Rahman, Faisal. "The effect of local culture-based material to improve reading ability of 8 th grade students at state junior high school 9 Yogyakarta." PROCEEDINGS OF THE 65th TEFLIN INTERNATIONAL CONFERENCE. Vol. 65. No. 01. 2019.

[26] Radha M K Nambiar1 , Noraini Ibrahim2 , Ruzy Suliza Hashim1, Ruhizan Mohammad Yasin3 , Hazita Azman1 , Noraini Mohd. Yusof2,*, Rashila Ramli2, Rosniah Mustaffa1. "Impact of Local Culture-Based Reading Materials on Students' Skill Development and Confidence in English". Universal Journal of Educational Research 8(2): 445-453, 2020 http://www.hrpub.org DOI: 10.13189/ujer.2020.080215. 2020.

[27] Azam Haji Othman, Noor, and James McLellan. "Brunei culture, English language: Textual reflections of an Asian culture located in the English-language output of Bruneians." Asian Englishes 3.1. 2000: 5-19.

[28] Mahboob, Ahmar. "English as an Islamic language: A case study of Pakistani English." World Englishes 28.2. 2009: 175-189.

[29] Amalia, Sholihati, and Wuri Wuryandani. "Socio-Cultural Based Learning Module for Critical Thinking Ability in Elementary School: Systematic Search." Acta Educationis Generalis 10.2. 2020: 180187

[30] Kasaian, Seyed Ahmad, and Rangaswamy Subbakrishna. "Iranian Parents' Resistance to Incompatible Aspects of Western Culture: Implications for ELT Material Development." English Language Teaching 4.1. 2011: 230-239. 